\title{
Amperometric Electrochemical Platform for Hydrazine Determination Exploiting Reduced Graphene Oxide, Co(Salophen) and DNA: Application in Pharmaceutical Formulations Samples
}

\author{
Ludymila V. Freitas, ${ }^{a}$ Kayni C. M. S. Lima,${ }^{b}$ Saimon M. Silva, ${ }^{c}$ Fernando R. F. Leite, ${ }^{a}$ \\ Ridvan N. Fernandes, ${ }^{b}$ Wallans T. P. Santos, ${ }^{d}$ Flavio S. Damos ${ }^{b}$ and Rita C. S. Luz ${ }^{*, b}$ \\ ${ }^{a}$ Departamento de Química, Universidade Federal dos Vales do Jequitinhonha e Mucuri, \\ 39100-000 Diamantina-MG, Brazil \\ ${ }^{b}$ Departamento de Química, Universidade Federal do Maranhão, 65080-805 São Luís-MA, Brazil \\ ${ }^{c}$ School of Chemistry, University of New South Wales, 2052 Sydney, Australia \\ ${ }^{d}$ Departamento de Farmácia, Universidade Federal dos Vales do Jequitinhonha e Mucuri, \\ 39100-000 Diamantina-MG, Brazil
}

\begin{abstract}
The present work presents the development of a sensitive and selective amperometric sensor for the determination of hydrazine (HZ) in pharmaceutical formulations using a glassy carbon electrode (GCE) modified with a composite based on Co(Salophen), reduced graphene oxide (rGO) and deoxyribonucleic acid (DNA). The rGO/Co(Salophen)/DNA composite was characterized by using Fourier-transform infrared spectroscopy (FTIR), cyclic voltammetry, and amperometry. The proposed platform presented a well-defined voltammetric profile with a redox couple around $0.32 \mathrm{~V} v \mathrm{~s} . \mathrm{Ag} / \mathrm{AgCl}$ which showed excellent catalytic activity towards $\mathrm{HZ}$ oxidation. The peak current of $\mathrm{HZ}$ electrochemical oxidation on the proposed electrochemical platform have changed linearly with the $\mathrm{HZ}$ concentration in the range from 2 to $364 \mu \mathrm{mol} \mathrm{L} \mathrm{L}^{-1}$. The proposed platform presented sensitivity, limit of detection, and limit of quantification of $0.056 \mu \mathrm{A} \mathrm{L} \mu \mathrm{mol}^{-1}, 0.54 \mu \mathrm{mol} \mathrm{L}^{-1}$, and $1.64 \mu \mathrm{mol} \mathrm{L} \mathrm{L}^{-1}$ to $\mathrm{HZ}$, respectively. The relative standard deviation for eight determinations using a solution of $50 \mu \mathrm{mol} \mathrm{L}{ }^{-1} \mathrm{HZ}$ was $0.85 \%$. The proposed sensor was successfully applied for the determination of $\mathrm{HZ}$ in pharmaceutical formulations, and the recovery tests showed a good accuracy with recovery percentage between 99 and $101 \%$.
\end{abstract}

Keywords: sensor, $\mathrm{Co}($ Salophen), reduced graphene oxide, DNA, hydrazine, pharmaceutical formulations

\section{Introduction}

Nowadays, the interest on hydrazine (HZ) has been increasing due to its high reactivity, which has been exploited in the production of a number of materials including insecticides and pesticides, as well as it has been employed in the preparation of some pharmaceutical formulations such as nifuroxazide, carbidopa, hydralazine, dihydralazine, isoniazid and iproniazide. ${ }^{1-4}$ On the other hand, the $\mathrm{HZ}$ is an extremely toxic compound as stated by some regulatory agencies such as the United States Environmental Protection Agency and the European Medicines Agency. 5,6

*e-mail: rita.luz@ufma.br
According to regulatory agencies, the recommended levels of $\mathrm{HZ}$ in medicinal products such as isoniazid based drugs is of $125 \mathrm{ppm}^{5,6}$ since the exposition to high levels of hydrazine can be harmful to human life because of its potential carcinogenic and mutagenic effects. ${ }^{5-7}$ In this sense, the monitoring of $\mathrm{HZ}$ in pharmaceutical formulations is of high importance to ensure the quality of the medicines released for consumption by the population.

The high importance of $\mathrm{HZ}$ in industrial, environmental and pharmaceutical fields have motivated the development of several analytical methodologies for $\mathrm{HZ}$ determination, such as spectrophotometry, ${ }^{8}$ injection analysis based systems, ${ }^{9}$ chromatographic methods, ${ }^{10,11}$ and electrochemical methods. ${ }^{12-15}$ The electrochemical methods present some interesting properties in comparison to the previously 
presented non-electrochemical methods, since they do not require long preparing steps, analytical grade reagents or skilled operators for the analysis. In this sense, the electrochemical methods show excellent performance for the determination of electroactive species in biological and environmental samples with good sensitivity, selectivity, low cost and high throughput. In addition, the electrochemical methods are portable, which facilitates the monitoring of molecules and the acquisition of information in situ and online. ${ }^{16-22}$

However, the main limitation related to the electrochemical determination of $\mathrm{HZ}$ with conventional electrodes is the exigence of a high overpotential to be applied in order to promote the electrochemical oxidation of HZ. A common strategy to detect HZ using electrochemical methods is the employment of chemically modified electrodes, which can improve the sensitivity and selectivity of the sensing device, improving the electrocatalytic activities for the electrochemical oxidation of HZ. ${ }^{23,24}$

Among the most promising nanomaterials, reduced graphene oxide (rGO) have been recognized as an excellent platform for the development of electrochemical sensors since they present exquisite properties including high electrical conductivity, excellent thermal and mechanical properties, large surface to volume ratio, and they show high susceptibility to chemical modification. ${ }^{25-28}$ However, many forms of graphene present low processability in a number of solvents as well as they require high electrochemical overpotentials to promote oxidation or reduction of many molecules. ${ }^{29}$ In this sense, the chemical functionalization of graphene with Schiff-base metal complexes and the use of dispersing agents have been performed in order to improve its processability. ${ }^{29,30}$

On the one hand, deoxyribonucleic acid (DNA) is an interesting alternative to improve the application of graphene as platform to the development of sensors since DNA can act as a dispersing agent by improving the dispersion of the graphene in aqueous medium. ${ }^{31,32}$ On the other hand, Schiff-bases based transition metals complexes present excellent versatility between electronic properties, stereo-chemical and high electrocatalytic activity for many molecules, which can be exploited by combining to graphene to give novel composite materials with high conductivity, good stability and catalytic activity. ${ }^{33,34}$

Herein, we report the development of a sensitive and selective sensor for the amperometric determination of $\mathrm{HZ}$ in pharmaceutical formulations using a composite based on $\mathrm{Co}$ (Salophen) modified rGO dispersed in DNA. The proposed $\mathrm{rGO} / \mathrm{Co}(\mathrm{Salophen}) / \mathrm{DNA} /$ glassy carbon electrode
(GCE) sensor presents low cost and can be applied for determination of $\mathrm{HZ}$ with high selectivity, precision, accuracy, and low response time.

\section{Experimental}

\section{Reagents and chemicals}

The graphite powder, hydrazine sulfate, doublestranded DNA (ds-DNA), boric acid, citric acid, disodium and monosodium phosphates, PIPES [piperazine- $N$ - $N$-bis(2-ethanesulfonic acid)], HEPES [N-(2-hydroxyethyl)piperazine- $N$-(2-ethanesulfonic acid)] and tris(hydroxymethyl) aminomethane were acquired from Sigma-Aldrich (São Paulo, Brazil). Co(Salophen) complex ( $N, N^{\prime}$-bis(salicylidene)1,2-phenylenediaminocobalt(II)) was prepared according to methods previously published. ${ }^{35,36}$

The standard solutions were prepared previously for each experiment by appropriate dilution of the stock solutions. All solutions were prepared with water purified in a Purelab Classic System from ELGA (Buckinghamshire, USA) and the actual $\mathrm{pH}$ of each solution was determined with a pH meter model Digimed DM-20 (São Paulo, Brazil). The $\mathrm{pH}$ of the solutions was adjusted adding $0.1 \mathrm{~mol} \mathrm{~L}^{-1} \mathrm{HCl}$ and $0.2 \mathrm{~mol} \mathrm{~L}^{-1} \mathrm{NaOH}$.

\section{Spectroscopic and electrochemical measurements}

Fourier-transform infrared (FTIR) spectra were obtained using a Shimadzu FTIR 8.400 (Tokyo, Japan). The samples were prepared at $1 \%$ in $\mathrm{KBr}$ tablets (rGO, $\mathrm{Co} /($ Salophen), rGO/Co(Salophen)). All electrochemical measurements were performed with an Autolab ${ }^{\circledR}$ PGSTAT $128 \mathrm{~N}$ potentiostat/galvanostat from Metrohm Autolab (Utrecht, Netherlands) coupled to a microcomputer and controlled by GPES 4.9 software.

\section{Preparation of reduced graphene oxide (rGO)}

$100 \mathrm{mg}$ of the graphite oxide was dissolved in purified water and dispersed with the aid of a sonicator. Then, the $\mathrm{pH}$ of the solution was adjusted to 10 with ammonium hydroxide and $88.67 \mathrm{mg}$ of hydrazine sulfate was added to mixture. The solution was refluxed for $60 \mathrm{~min}$ at $95^{\circ} \mathrm{C}$. The dispersion was left to cool and potassium chloride $(\mathrm{KCl})$ was added to dispersion in order to favor the precipitation process by salting out effect. Finally, the dispersion containing reduced graphene oxide was filtered and was left to dry at a $60{ }^{\circ} \mathrm{C}$. 


\section{Sensor construction}

A dispersion was prepared by mixing $3 \mathrm{mg}$ of the reduced graphene oxide modified with $\mathrm{Co}$ (Salophen) complex with $1 \mathrm{~mL}$ of $2 \mathrm{mg} \mathrm{mL}^{-1} \mathrm{DNA}$ dispersion. In order to modify the GCE with the composite, the surface of the GCE was polished with alumina slurry and, subsequently, it was copiously washed with water to remove any previously adsorbed material. $10 \mu \mathrm{L}$ of the dispersion was dropped on the surface of the electrode and the set was left to dry at $60{ }^{\circ} \mathrm{C}$ for $10 \mathrm{~min}$ to obtain the $\mathrm{rGO} / \mathrm{Co}$ (Salophen)/DNA modified electrode.

Preparation of the samples and electrochemical determination of $\mathrm{HZ}$

Drugs samples containing isoniazid (INH) from two different laboratories were purchased at local drugstores. The nominal values of INH and rifampicin (RF), for each capsule, were 200 and $300 \mathrm{mg}$, respectively. The content of 5 capsules was macerated and $500.4 \mathrm{mg}$ of the powder was weighed and dispersed in water. The dispersion was filtered, transferred to a volumetric flask, and the volume was adjusted with water to $100 \mathrm{~mL}$. The electrochemical analysis of each sample was performed by mixing an aliquot of $500 \mu \mathrm{L}$ of the sample to $9.5 \mathrm{~mL}$ of the PBS (phosphatebuffered saline) buffer solution in the electrochemical cell.

\section{Results and Discussion}

\section{Composite characterization}

The Fourier transformed infrared spectrum of $\mathrm{rGO}$ presented two peaks at 3500 and $1600 \mathrm{~cm}^{-1}$ corresponding to the stretching and bending vibration of $\mathrm{OH}$ groups of water molecules adsorbed on rGO (Figure 1a). The symmetric and anti-symmetric stretching vibrations of $\mathrm{CH}_{2}$ of the rGO were verified at 2930 and $2859 \mathrm{~cm}^{-1}$, respectively. The stretching vibration of $\mathrm{C}=\mathrm{O}$ of carboxylic acid and carbonyl groups present at the edges of graphene were verified at 1630 and $740 \mathrm{~cm}^{-1}$, respectively. ${ }^{37}$ Although the graphite oxide had been reduced by hydrazine route, peaks at 1385 and $1110 \mathrm{~cm}^{-1}$ corresponding to the stretching vibration of $\mathrm{C}-\mathrm{C}$ of carboxylic acid and $\mathrm{C}-\mathrm{OH}$ of alcohol were observed in FTIR spectrum of rGO, justifying the hydrophilic nature of obtained reduced graphene oxide. ${ }^{38}$ On the other hand, the FTIR spectrum of the Co(Salophen) (Figure 1b) presented vibrations of specific groups verified in molecular structure of the $\mathrm{Co}$ (Salophen) complex. ${ }^{39}$

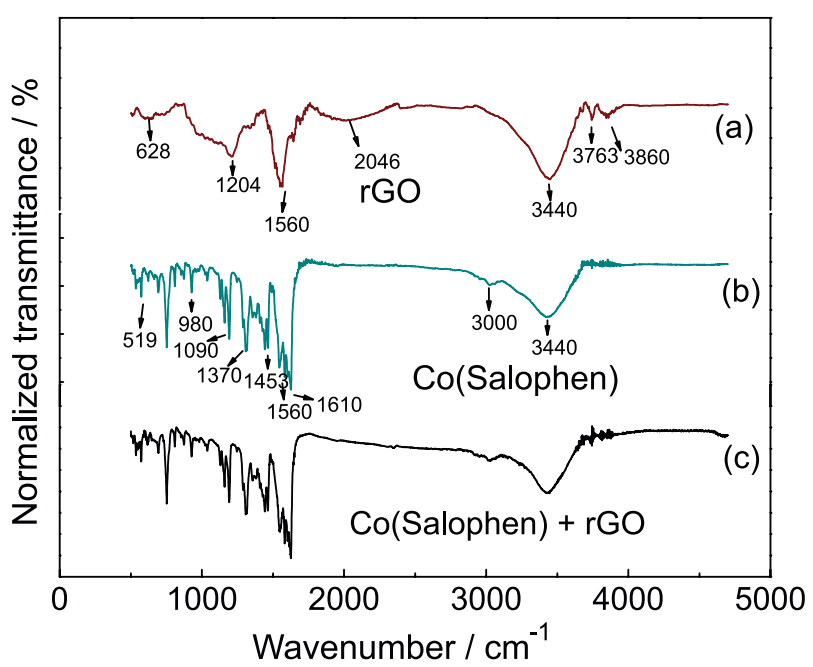

Figure 1. FTIR analyses of (a) graphene; (b) $\mathrm{Co}(\mathrm{Salophen})$; and (c) graphene/Co(Salophen).

The spectrum $\mathrm{c}$ in Figure 1 obtained for the $\mathrm{rGO} / \mathrm{Co}($ Salophen) composite indicates that the interaction between reduced graphene oxide and Co(Salophen) occurred through a physical adsorption. As can be seen, the characteristic bands of compounds observed in spectra $1 \mathrm{a}$ and $1 \mathrm{~b}$ were observed in spectrum $1 \mathrm{c}$.

\section{Electrochemical behavior of hydrazine on $\mathrm{rGO} / \mathrm{Co}($ Salophen)/} DNA/GCE

Firstly, cyclic voltammograms (CV) for $\mathrm{HZ}$ oxidation were performed with different electrodes in $0.1 \mathrm{~mol} \mathrm{~L}^{-1}$ PBS ( $\mathrm{pH} 7$ ) as supporting electrolyte in order to evaluate the electrocatalytic behavior of the $\mathrm{rGO} /$ Co(Salophen)/DNA modified electrode to HZ. Figure 2 shows CV obtained in the absence (Figure 2, curve d) and presence (Figure 2, curve e) of $0.3 \mathrm{mmol} \mathrm{L}^{-1} \mathrm{HZ}$ for the $\mathrm{rGO} / \mathrm{Co}$ (Salophen)/DNA/GCE, which were compared to $\mathrm{CV}$ of the bare GCE (Figure 2, curve a), rGO/DNA/GCE (Figure 2, curve b) and Co(Salophen)/ DNA/GCE (Figure 2, curve c) in presence of HZ.

In Figure 2 (curve a), the anodic peak potential for oxidation of $\mathrm{HZ}$ at bare electrode occurs in an overpotential of between 700 and $800 \mathrm{mV}$, suggesting that the electron transfer between the surface of the bare electrode and the HZ is kinetically slow. On the other hand, the electrocatalytic oxidation of $\mathrm{HZ}$ occurred at about $490 \mathrm{mV}$ (Figure 2, curve b) when the electrode surface was modified with rGO/DNA film, which is shifted about $300 \mathrm{mV}$ vs. Ag/AgCl toward less positive values in comparison to the bare electrode.

The curve $\mathrm{c}$ in Figure 2 presents the cyclic voltammogram referring to $\mathrm{HZ}$ oxidation on the Co(Salophen)/DNA electrode. It was observed a significant 


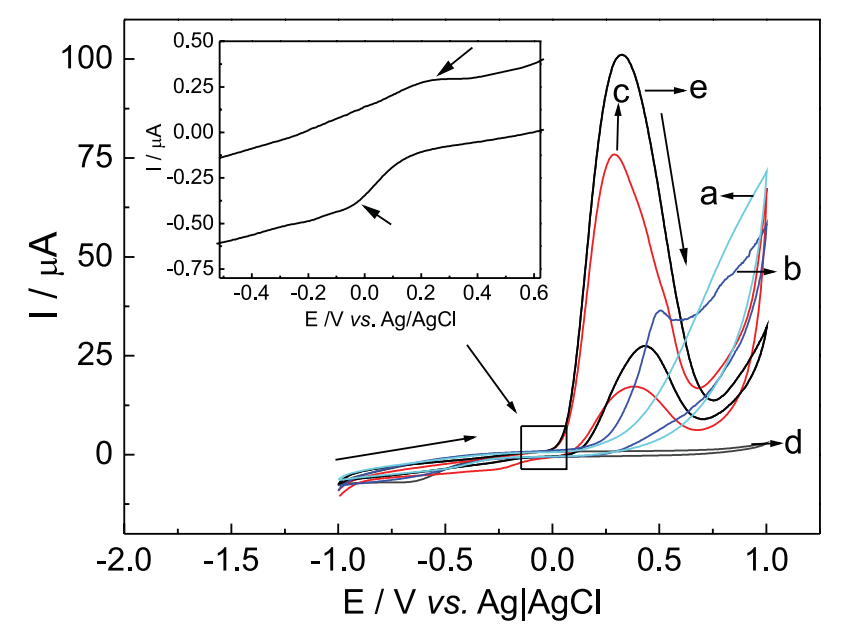

Figure 2. CVs of the bare (a) GCE; (b) rGO/DNA/GCE; and (c) $\mathrm{Co}($ Salophen $) / \mathrm{DNA} / \mathrm{GCE}$ in the presence of HZ. CVs of the $\mathrm{rGO} / \mathrm{Co}$ (Salophen)/DNA/GCE: in (d) absence (voltammogram insert) and (e) presence of the HZ. Measurements were carried out in $0.1 \mathrm{~mol} \mathrm{~L}^{-1}$ PBS; pH 7; $[\mathrm{HZ}]=0.3 \mathrm{mmol} \mathrm{L}^{-1} ;[\mathrm{Co}($ Salophen $)]=1 \mathrm{mmol} \mathrm{L}^{-1}$; $[\mathrm{rGO}]=3 \mathrm{mg} \mathrm{mL}^{-1} ;[$ DNA $]=2 \mathrm{mg} \mathrm{mL}^{-1} ; \mathrm{v}=0.025 \mathrm{~V} \mathrm{~s}^{-1}$.

increase of the anodic peak current of $\mathrm{HZ}$ with a shift of the anodic peak of $\mathrm{HZ}$ to about $280 \mathrm{mV} v s$. $\mathrm{Ag} / \mathrm{AgCl}$, which can be attributed to the electrocatalytic activity of $\mathrm{Co}$ (Salophen) complex.

The $\mathrm{CV}$ of the $\mathrm{rGO} / \mathrm{Co}$ (Salophen)/DNA modified electrode in the absence (Figure 2, curve d) showed a redox couple indicating the process of oxidation and reduction of cobalt complex $\mathrm{Co}^{\mathrm{II}} / \mathrm{Co}^{\mathrm{I}}$ on the electrode surface. Upon addition of $0.3 \mathrm{mmol} \mathrm{L}^{-1} \mathrm{HZ}$ (curve e), there is a dramatic enhancement of the anodic peak current and the cathodic peak current disappeared completely as expected from an electrocatalytic process. $^{40}$

In order to investigate the nature of the electrocatalytic oxidation of hydrazine on the $\mathrm{rGO} / \mathrm{Co}$ (Salophen)/DNA modified electrode, it was carried out $\mathrm{CV}$ at several scan rates. The plot of $I_{p} v s . v^{1 / 2}$ (Figure 3a) shows a linear relationship, suggesting that the process is controlled by mass transport and indicating that the system is an irreversible process controlled by diffusion.

Assuming an irreversible oxidation, the following equation was employed to calculate the number of electrons (n) involved in the overall reaction from the slope of the plot of $\mathrm{I}_{\mathrm{p}}$ versus $\mathrm{v}^{1 / 2}: 41,42$

$\mathrm{I}_{\mathrm{p}}=\left(2.99 \times 10^{5}\right)\left[(1-\alpha) \mathrm{n}_{\mathrm{a}}\right]^{1 / 2} \mathrm{nACD}^{1 / 2} \mathrm{v}^{1 / 2}$

where $I_{p}$ is the peak current $(A), n_{a}$ represents the number of electrons involved in the rate-determining step (in this case the $n_{a}$ value used was 1), $n$ the number of total electrons involved in the reaction of the electroactive specie $\left(\mathrm{cm}^{2} \mathrm{~s}^{-1}\right)$, A the area $\left(\mathrm{cm}^{2}\right), \mathrm{C}\left(0.3 \times 10^{-6} \mathrm{~mol} \mathrm{~cm} \mathrm{~cm}^{-3}\right)$
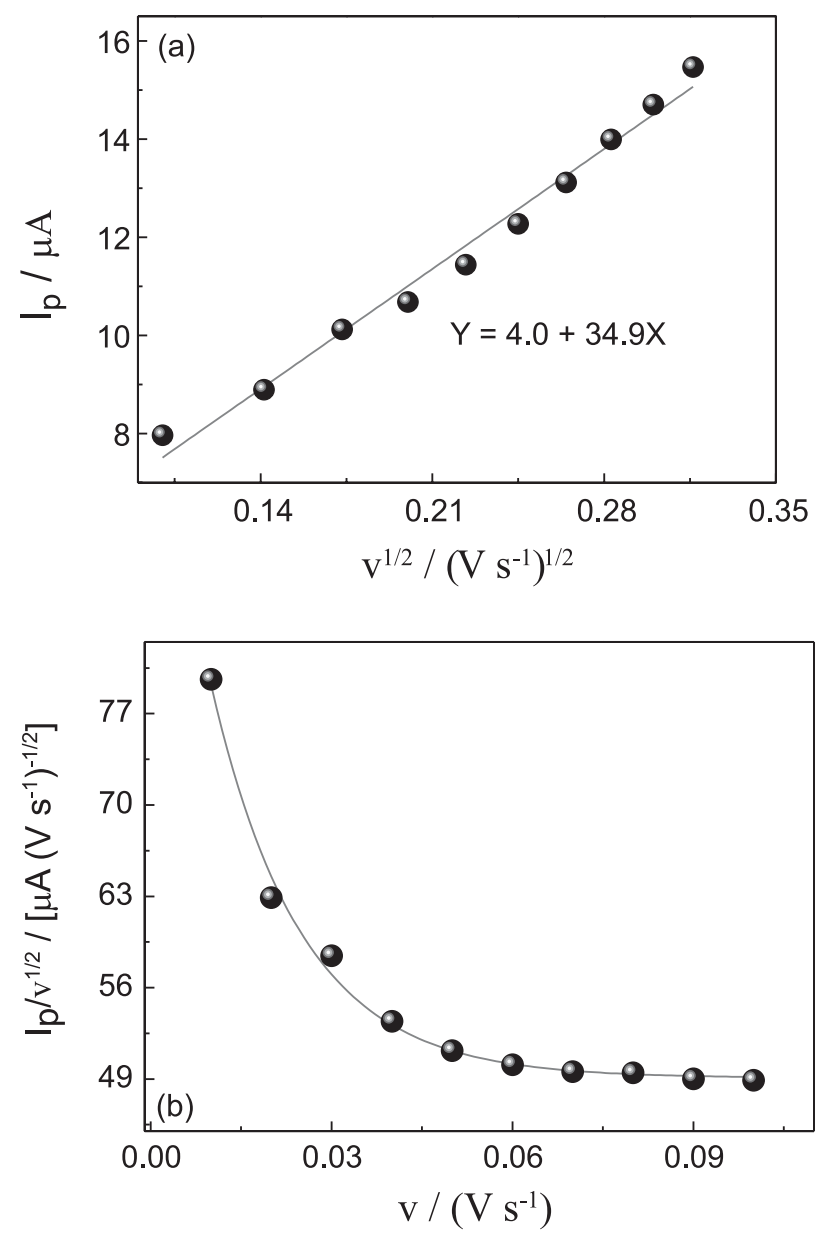

Figure 3. (a) Plot of peak current $\left(\mathrm{I}_{\mathrm{p}}\right)$ versus the square root of scan rate for the $\mathrm{rGO} / \mathrm{Co}$ (Salophen)/DNA modified electrode; (b) plot of $\left(\mathrm{I}_{\mathrm{p}} / \mathrm{v}^{1 / 2}\right)$ versus the scan rate. Date obtained from the Figure $3 \mathrm{a}: \mathrm{v}=0.01$, $0.02,0.03,0.04,0.05,0.06,0.07,0.08,0.09$ and $0.1 \mathrm{~V} \mathrm{~s}^{-1}$.

is the concentration of the electroactive species, and $\mathrm{v}$ is the potential scan rate $\left(\mathrm{V} \mathrm{s}^{-1}\right)$. The diffusion coefficient of HZ used was $5.9 \times 10^{-6} \mathrm{~cm}^{2} \mathrm{~s}^{-1} .{ }^{43}$

The approach utilized to get the value of $\alpha$ for $\mathrm{HZ}$ oxidation was based on the difference between the peak potential $\left(\mathrm{E}_{\mathrm{p}}\right)$ and the potential where the current is half the peak current value $\left(\mathrm{E}_{\mathrm{p} / 2}\right)$, according to the following equation: ${ }^{42}$

$1-\alpha=\frac{47.7 m V}{E_{p}-E_{p / 2}}$

In this sense, the value calculated for $\alpha$ was 0.32 and the value of $n$ determined was 4.04 suggesting an electron transfer mechanism of four electrons for the electrocatalytic oxidation of HZ. Additionally, the plot of $\mathrm{I}_{\mathrm{p}} / \mathrm{v}^{1 / 2} v s$. scan rate (Figure $3 b$ ) shows a typical electrocatalytic-catalytic behavior to the oxidation process of the $\mathrm{HZ}$ on the $\mathrm{rGO}$ / Co(Salophen)/DNA/GCE. 
Effects of the concentrations of rGO, Co(Salophen), and $\mathrm{pH}$ on the electrocatalytic oxidation of $\mathrm{HZ}$

The response of the $\mathrm{rGO} / \mathrm{Co}$ (Salophen)/DNA/GCE to $\mathrm{HZ}$ can be affected by $\mathrm{rGO}$ and $\mathrm{Co}$ (Salophen) concentrations. The concentration of DNA film was kept constant at $2 \mathrm{mg} \mathrm{mL}^{-1}$ for all experiments. $\mathrm{CV}$ of the electrode modified with several concentrations of rGO and $\mathrm{Co}$ (Salophen) were performed in the presence of $0.3 \mathrm{mmol} \mathrm{L}^{-1} \mathrm{HZ}$, to obtain the optimal concentrations of $\mathrm{rGO}$ and $\mathrm{Co}$ (Salophen) for the electrochemical oxidation of $\mathrm{HZ}$ on $\mathrm{rGO} / \mathrm{Co}$ (Salophen)/DNA/GCE.

The amount of immobilized rGO on the surface of electrode was controlled by using the same volume of the suspension at different concentrations of rGO (2.0; 2.5; $3.0 ; 3.5$ and $\left.4.0 \mathrm{mg} \mathrm{mL}^{-1}\right)$ maintaining fixed concentrations of Co(Salophen) $\left(1 \mathrm{mmol} \mathrm{L}^{-1}\right)$ and DNA $\left(2 \mathrm{mg} \mathrm{mL}^{-1}\right)$. The effect of the rGO amount on the sensor response is shown in Table S1 (Supplementary Information (SI) section). As can be seen, the peak current for $\mathrm{HZ}$ oxidation increased when the rGO concentration increased from 2.5 to $3.0 \mathrm{mg} \mathrm{mL}^{-1}$. In this sense, the $\mathrm{rGO}$ concentration was kept at $3.0 \mathrm{mg} \mathrm{mL}^{-1}$ for all subsequent measurements in order to find the better stability of the film and response toward HZ oxidation.

The Co(Salophen) concentration also affects the sensor response (Table S1, SI section). As can be observed in Table S1, the anodic peak current toward HZ oxidation increased when the complex concentration increased from 0.01 to $1.0 \mathrm{mmol} \mathrm{L}^{-1}$. Sensors constructed from solutions with $\mathrm{Co}$ (Salophen) concentrations lower than $1.0 \mathrm{mmol} \mathrm{L}^{-1}$ showed low peak currents toward HZ oxidation. In addition, sensors prepared with $\mathrm{Co}$ (Salophen) concentrations higher than $1.0 \mathrm{mmol} \mathrm{L}^{-1}$ were also inefficient to provoke the electrocatalysis of the $\mathrm{HZ}$ oxidation. Then, all subsequent sensors were prepared with $1.0 \mathrm{mmol} \mathrm{L}^{-1}$ of $\mathrm{Co}$ (Salophen), $2 \mathrm{mg} \mathrm{mL}^{-1}$ of DNA, and $3.0 \mathrm{mg} \mathrm{mL}^{-1}$ of rGO.

The influence of the solution $\mathrm{pH}$ on the electrochemical response of $\mathrm{HZ}$ was also investigated for $0.1 \mathrm{~mol} \mathrm{~L}^{-1}$ PBS with pH values between 6.5 and 8.5 (Figure S1a, SI section). The experimental results indicate that $\mathrm{pH}$ has a significant influence on the values of the anodic peak current (Figure S1a, SI section) and peak potential (Figure S1b, SI section). According to Figure S1a, the maximum value of peak current was obtained at $\mathrm{pH} 7.0$, probably due to the higher stability of the modifier (rGO/Co(Salophen)/DNA) on the surface of the electrode, thus favoring a greater current for the oxidation of hydrazine. In this sense, the optimum $\mathrm{pH}$ for further studies was fixed at 7.0.

The anodic peak potential $\left(\mathrm{E}_{\mathrm{pa}}\right)$ shifted to negative potentials with an increase of $\mathrm{pH}$ values (Figure $\mathrm{S} 1 \mathrm{~b}$, SI section). The $\mathrm{E}_{\mathrm{pa}}$ values shift linearly with changes in $\mathrm{pH}$ values with a correlation coefficient of 0.999 and a slope of $-0.073 \mathrm{~V}$ per $\mathrm{pH}$ at $25^{\circ} \mathrm{C}$. The obtained slope is close to that expected for an electrode reaction based on one proton/one electron $(0.060 \mathrm{~V}$ per $\mathrm{pH}) .^{42}$

The effect of the buffer solution on the peak current with the sensor for HZ was also investigated. Figure S1c (SI section) shows the response of the $\mathrm{rGO} / \mathrm{Co}$ (Salophen)/DNA modified electrode in different buffer solutions, such as: PBS, HEPES, Britton-Robinson (BR) and Tris at concentration of $0.1 \mathrm{~mol} \mathrm{~L}^{-1}, \mathrm{pH}$ 7. The best response towards $\mathrm{HZ}$ oxidation was obtained using PBS, which may be associated to the high ionic mobility of the phosphate ions, by faciliting the electronic transfer between the electrode and the solution. In this sense, the PBS was chosen for further experiments.

The applied potential $\left(\mathrm{E}_{\text {appl. }}\right)$ was verified after the optimization of experimental conditions. Thus, an initial study was performed in order to determine the best potential to be applied to the electrode $(0.20 ; 0.24 ; 0.30$; $0.32 ; 0.36 ; 0.40 ; 0.43$ and $0.46 \mathrm{~V} v s . \mathrm{Ag} / \mathrm{AgCl})$. Figure S1d (SI section) shows the sensor response time (lower than $1 \mathrm{~s}$ ) and the values of the currents observed for these potentials were, respectively, $7.30 \pm 0.12 ; 8.60 \pm 0.10$; $9.46 \pm 0.09 ; 9.70 \pm 0.05 ; 9.69 \pm 0.04 ; 8.89 \pm 0.11$; $8.20 \pm 0.02$; and $7.30 \pm 0.01 \mu \mathrm{A}$. According to these results, high current values were obtained between 0.3 and $0.36 \mathrm{~V}$ due to total oxidation of $\mathrm{HZ}$ in these potentials. In this sense, the chosen potential for the following experiments was $0.32 \mathrm{~V}$.

Analytical characterization of the $\mathrm{rGO} / \mathrm{Co}$ (Salophen)/DNA modified electrode

Figure 4 shows the amperometric response and analytical curves recorded for the $\mathrm{rGO} / \mathrm{Co}$ (Salophen)/DNA modified electrode under optimized conditions for different concentrations of HZ. The proposed sensor showed a linear response range from 2 to $364 \mu \mathrm{mol} \mathrm{L}^{-1}$ with $\mathrm{r}^{2}=0.999$, which can be expressed in the following equation:

$\Delta \mathrm{I}(\mu \mathrm{A})=(0.752 \pm 0.103)+(0.056 \pm 0.007)[\mathrm{HZ}]\left(\mu \mathrm{mol} \mathrm{L} \mathrm{L}^{-1}\right)$

A limit of detection of $0.54 \mu \mathrm{mol} \mathrm{L^{-1 }}$ was determined using a $3 \mathrm{~s} / \mathrm{b}$ slope ratio and the limit of quantification was $1.64 \mu \mathrm{mol} \mathrm{L} \mathrm{L}^{-1}$ using $10 \mathrm{~s} / \mathrm{b}$ slope, where $\mathrm{s}$ is the standard deviation of the mean value for ten amperograms of the blank determined according to the IUPAC recommendations and $b$ is the angular coefficient of analytical curve. Table S2 (SI section) shows that the results obtained in the present work are comparable to the results found in literature. . $3,44-60^{-}$ 

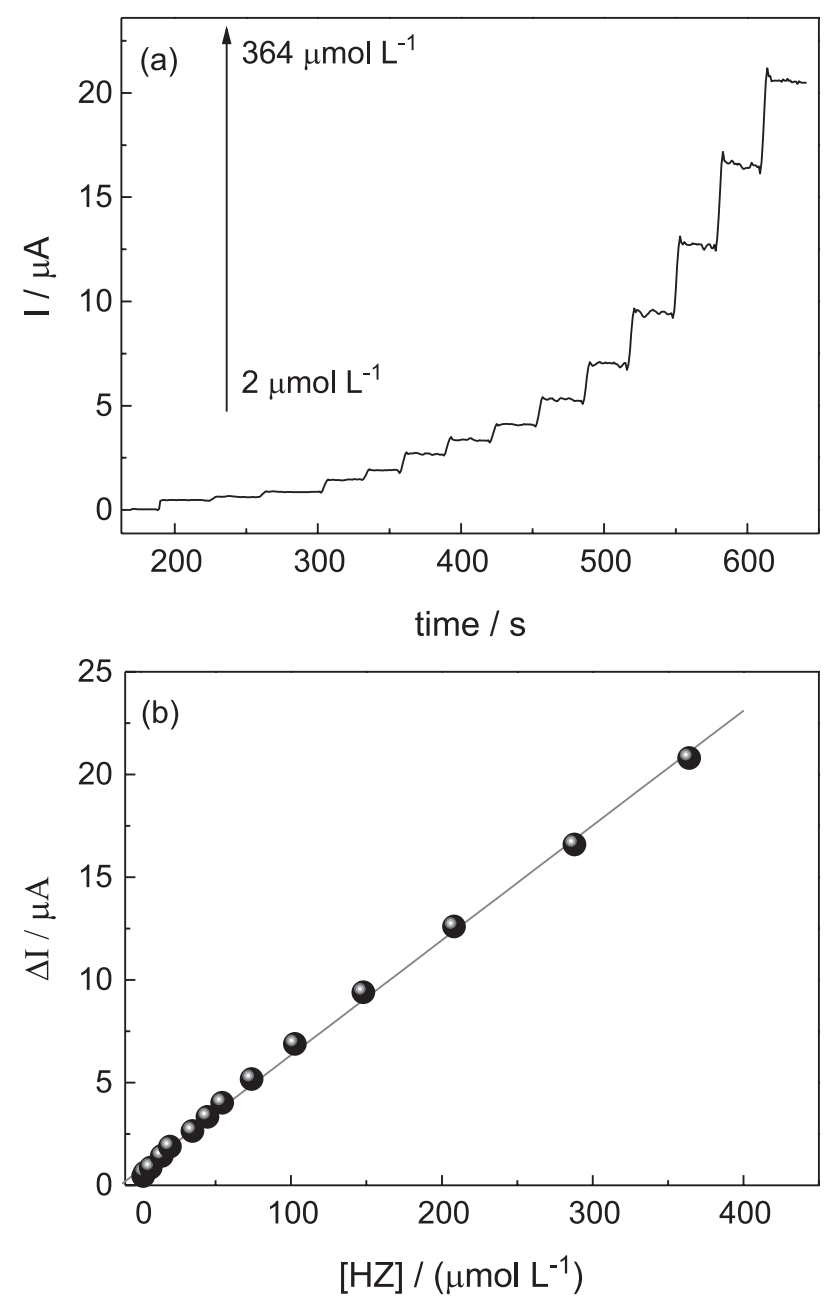

Figure 4. (a) Amperometric I-t curve for the determination of $\mathrm{HZ}$ at $\mathrm{rGO} / \mathrm{Co}$ (Salophen)/DNA modified electrode; (b) analytical curve for the oxidation of $\mathrm{HZ}$ in $0.1 \mathrm{~mol} \mathrm{~L}^{-1} \mathrm{PBS}$ at $\mathrm{pH} 7.0$ for the concentrations: $2 ; 3 ; 7 ; 14 ; 20 ; 35 ; 45 ; 54 ; 74 ; 103 ; 148 ; 208 ; 288$ and $364 \mu \mathrm{mol} \mathrm{L}^{-1}$ of HZ. $\mathrm{E}_{\text {appl. }}=0.32 \mathrm{~V}$.

The relative standard deviation (RSD) for eight determinations of $50 \mu \mathrm{mol} \mathrm{L}^{-1} \mathrm{HZ}$ was $0.8 \%$. Additionally, a series of eight sensors were prepared and tested under the same conditions, resulting in an RSD of $1.03 \%$ of the electrochemical responses. These results indicate that the $\mathrm{rGO} / \mathrm{Co}$ (Salophen)/DNA modified electrode has good stability and repeatability, probably due to the ability of graphene and DNA in fixing Co(Salophen) compound on the electrode surface in a stable and reproducible way.

The stability of the $\mathrm{rGO} / \mathrm{Co}$ (Salophen)/DNA modified electrode was checked in the presence of $50 \mu \mathrm{mol} \mathrm{L}^{-1} \mathrm{HZ}$ performing successive voltammetric measurements

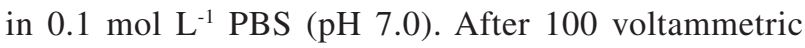
measurements no change was observed in the response of the modified electrode. When the modified electrode was stored at room temperature no significant change in the response was observed for more than two months.
Interfering studies

In order to verify the selectivity of the proposed method, $\mathrm{rGO} / \mathrm{Co}$ (Salophen)/DNA/GCE was used for the determination of impurities of $\mathrm{HZ}$ that may be present in the isoniazid based drugs, investigating possible interferences of chemical species that are often found in the analyzed tablet samples. Table S3 (SI section) shows the relative responses for the analytical signal intensities obtained using a solution of $50 \mu \mathrm{mol} \mathrm{L}{ }^{-1} \mathrm{HZ}$ and the same solutions enriched with the interfering in 1:1 ratio. The study was performed under optimized experimental and operational conditions and the amperograms were obtained in triplicate for greater reliability of the results.

As presented in Table S3 (SI section), the compounds ascorbic acid, isoniazide, thiosulfate, rifampicin and magnesium stearate did not present significant interference on the voltammetric response to $\mathrm{HZ}$, which classifies the proposed sensor as selective for the determination of the analyte mentioned in pharmaceutical samples. This finding might be related to the fact that the analyzed compounds have higher oxidation potentials than HZ.

Determination of $\mathrm{HZ}$ in pharmaceutical samples employing $\mathrm{rGO} / \mathrm{Co}$ (Salophen)/DNA/GCE and addition and recovery tests

The proposed sensor was applied to drugs used in the treatment of tuberculosis (isoniazid) and the results regarding to the found $\mathrm{HZ}$ concentrations in laboratory samples A and B are presented in the Table 1. The analytical curve for each sample was obtained by relating the amounts of $\mathrm{HZ}$ added to the sample to the respective $\Delta \mathrm{I}_{\mathrm{pa}}$ determined by amperometry under optimized experimental and operational conditions. According to the results, it can be observed that the amount of $\mathrm{HZ}$ determined in both samples $\mathrm{A}$ and $\mathrm{B}$ was lower than the maximum allowed $\mathrm{HZ}$ value in isoniazid drugs $\left(125 \mathrm{ppm}\right.$ or $\left.3.9 \mathrm{mmol} \mathrm{L}^{-1}\right){ }^{5,6}$

The accuracy of the proposed procedure was investigated through the addition and recovery experiments that were performed by adding two known quantities of the analyte in the samples (Table 1). The recovery percentage was given by the ratio of the total $\mathrm{HZ}$ concentration (sample + standard added) found and the expected total concentration multiplied by 100 . The addition and recovery tests were performed in triplicate for greater reliability of the results. It is suggested, through the presented results, that the sensor allowed a good recovery for the HZ in the samples of the capsules analyzed, with values of recovery between 99 and $101 \%$, suggesting a good accuracy of the proposed method. 
Table 1. Recovery values of HZ obtained for 2 pharmaceutical samples

\begin{tabular}{lcccc}
\hline Sample $(\mathrm{n}=2)$ & {$[\mathrm{HZ}]$ added $/\left(\mu \mathrm{mol} \mathrm{L}^{-1}\right)$} & {$[\mathrm{HZ}]$ expected $/(\mu \mathrm{mol} \mathrm{L}-1)$} & $[\mathrm{HZ}]$ found / $\left.(\mu \mathrm{mol} \mathrm{L})^{-1}\right)$ & Recovery $/ \%^{\mathrm{a}} \%$ \\
\hline & 0.00 & - & $5.00 \pm 0.10$ & - \\
A & 10.00 & 15.00 & $15.10 \pm 0.10$ & 101 \\
& 100.00 & 105.00 & $104.80 \pm 0.50$ & - \\
B & 0.00 & - & $100 \pm 0.30$ & 99 \\
& 10.00 & 17.00 & $16.90 \pm 0.20$ & 100 \\
\hline
\end{tabular}

aThe standard deviation for the measurements were inferior to $1 \%$.

\section{Conclusions}

This work shows that a GCE modified with $\mathrm{rGO} /$ $\mathrm{Co}$ (Salophen)/DNA is a feasible alternative for analytical determination of $\mathrm{HZ}$ in pharmaceutical samples used in the treatment of tuberculosis. Optimization of the experimental conditions resulted in a limit of detection and sensitivity for $\mathrm{HZ}$ better than those described in the literature. This sensor showed good repeatability for both the measurements and electrode preparation, evaluated in terms of relative standard deviations. Moreover, the method showed a good percentage of recovery for the samples; therefore, it can be concluded that the $\mathrm{rGO} / \mathrm{Co}$ (Salophen)/DNA/GCE is a sensitive, robust, and stable sensor for HZ determination in pharmaceutical samples.

\section{Supplementary Information}

Supplementary data are available free of charge at http://jbcs.sbq.org.br as PDF file.

\section{Acknowledgments}

The authors are grateful to Conselho Nacional de Desenvolvimento Científico e Tecnológico (CNPq) and Instituto Nacional de Ciência e Tecnologia (INCT) Bioanalítica.

\section{References}

1. Elder, D. P.; Snodin, D.; Teasdale, A.; J. Pharm. Biomed. 2011, 54, 900.

2. Goswami, S.; Das, S.; Aich, K.; Sarkar, D.; Mondal, T. K.; Tetrahedron Lett. 2014, 55, 2695.

3. Khan, M.; Kumar, S.; Jayasree, K.; Reddy, K. V. S. R. K.; Dubey, P. K.; Chromatographia 2013, 76, 801.

4. Shukla, S.; Chaudhary, S.; Umar, A.; Chaudhary, G. R.; Mehta, S. K.; Sens. Actuators, B 2014, 196, 231.
5. Kean, T.; Miller, J. H.; Skellern, G. G.; Snodin, D.; Pharmeur. Sci. Notes 2006, 2006, 23.

6. Mehta, S. K.; Singh, K.; Umar, A.; Chaudhary, G. R.; Singh, S.; Electrochim. Acta 2012, 69, 128.

7. Zhang, Y.; Han, T. Y.; Wang, Z. Y.; Zhao, C.; Li, J. N.; Fei, T.; Liu, S.; Lu, G. Y.; Zhang, T.; Sens. Actuators, B 2017, 243, 1231.

8. Mitic, V. D.; Nikolic, S. D.; Stankov-Jovanovic, V. P.; Cent. Eur. J. Chem. 2010, 8, 559.

9. Yu, L.; Zhang, X. S.; Yu, L.Y.; Adv. Mater. Res. 2012, 130, 396.

10. Oh, J. A.; Park, J. H.; Shin, H. S.; Anal. Chim. Acta 2013, 769 , 79.

11. Smolenkov, A. D.; Chernobrovkina, A. V.; Smirnov, R. S.; Shpigun, O. A.; J. Anal. Chem. 2012, 67, 360.

12. Kocak, S.; Altin, A.; Kocak, C. C.; Anal. Lett. 2016, 49 , 1015.

13. Lee, J. Y.; Nguyen, T. L.; Park, J. H.; Kim, B. K.; Sensors 2016 , $16,647$.

14. Mohammadi, S. Z.; Beitollahi, H.; Asadi, E. B.; Environ. Monit. Assess. 2015, 187, 122.

15. Mozloum-Ardakani, M.; Karimi, M. A.; Zare, M. M.; Mirdehghan, S. M.; Int. J. Electrochem. Sci. 2008, 3, 246.

16. Beitollahi, H.; Tajik, S.; Parvan, H.; Soltani, H.; Akbari, A.; Asadi, M. H.; Anal. Bioanal. Electrochem. 2014, 6, 54.

17. Moghaddam, H. M.; Beitollahi, H.; Tajik, S.; Malakootian, M.; Karimi-Maleh, H.; Environ. Monit. Assess. 2014, 186, 7431.

18. Beitollahi, H.; Tajik, S.; Mohammadi, S. Z.; Baghayeri, M.; Ionics 2014, 20, 571.

19. Tajik, S.; Taher, M. A.; Beitollahi, H.; Ionics 2014, 20, 1155.

20. Baghbamidi, S. E.; Beitollahi, H.; Mohammadi, S. Z.; Tajik, S.; Soltani-Nejad, S.; Soltani-Nejad, V.; Chin. J. Catal. 2013, 34, 1869.

21. Beitollahi, H.; Tajik, S.; Karimi-Maleh, H.; Hosseinzadeh, R.; Appl. Organomet. Chem. 2013, 27, 444.

22. Beitollahi, H.; Karimi-Maleh, H.; Khabazzadeh, H.; Anal. Chem. 2008, 80, 9848.

23. Kim, S. P.; Choi, H. C.; Sens. Actuators, B 2015, 207, 424.

24. Prathap, M. U. A.; Anuraj, V.; Satpati, B.; Srivastava, R.; J. Hazard. Mater. 2013, 262, 766. 
25. Silva, S. M.; Aguiar, L. F.; Carvalho, R. M. S.; Tanaka, A. A.; Damos, F. S.; Luz, R. C. S.; Microchim. Acta 2016, 183, 1251.

26. Huang, Y.; Liang, J. J.; Chen, Y. S.; Small 2012, 8, 1805.

27. Novoselov, K. S.; Geim, A. K.; Morozov, S. V.; Jiang, D.; Zhang, Y.; Dubonos, S. V.; Grigorieva, I. V.; Firsov, A. A.; Science 2004, 306, 666.

28. Ratinac, K. R.; Yang, W. R.; Gooding, J. J.; Thordarson, P.; Braet, F.; Electroanalysis 2011, 23, 803.

29. Ribeiro, I. A. L.; Yotsumoto-Neto, S.; dos Santos, W. T. P.; Fernandes, R. N.; Goulart, M. O. F.; Damos, F. S.; Luz, R. C. S.; J. Braz. Chem. Soc. 2017, 28, 1768.

30. Sarvestani, A. H.; Mohebbi, S.; J. Chem. Res. 2006, 4, 257.

31. Premkumar, T.; Geckeler, K. E.; Prog. Polym. Sci. 2012, 37, 515.

32. Zhang, Q. A.; Qiao, Y.; Hao, F.; Zhang, L.; Wu, S. Y.; Li, Y.; Li, J. H.; Song, X. M.; Chem. - Eur. J. 2010, 16, 8133.

33. Dong, Y. W.; Fan, R. Q.; Wang, P.; Wei, L. G.; Wang, X. M.; Zhang, H. J.; Gao, S.; Yang, Y. L.; Wang, Y. L.; Dalton Trans. 2015, 44, 5306.

34. Kostova, I.; Saso, L.; Curr. Med. Chem. 2013, 20, 4609.

35. Smith, C. W.; Loon, G. W. V.; Baird, M. C.; Can. J. Chem. 1976, $54,1875$.

36. Tauzher, G.; Mestroni, G.; Puxeddu, A.; Costanzo, R.; Costa, G.; J. Chem. Soc. A 1971, 2504.

37. Lima, K. C. M. S.; Santos, A. C. F.; Fernandes, R. N.; Damos, F. S.; Luz, R. C. S.; Microchem. J. 2016, 128, 226.

38. Chai, P. J.; Li, Y. S.; Tan, C. X.; Chin. Chem. Lett. 2011, 22, 1403.

39. Zhu, D. J.; Mei, F. M.; Chen, L. J.; Mo, W. L.; Li, T.; Li, G. X.; Fuel 2011, 90, 2098.

40. Luz, R. D. S.; Damos, F. S.; Tanaka, A. A.; Kubota, L. T.; Gushikem, Y.; Electrochim. Acta 2008, 53, 4706.

41. Andrieux, C. P.; Saveant, J. M.; J. Electroanal. Chem. 1978, 93, 163.

42. Bard, A. J.; Faulkner, L. R.; Electrochemical Methods: Fundamentals and Applications, $2^{\text {nd }}$ ed.; Wiley: New York, 2001.

43. Duarte, J. C.; Luz, R. D. C. S.; Damos, F. S.; de Oliveira, A. B.; Kubota, L. T.; J. Solid State Electrochem. 2007, 11, 631.
44. Benvidi, A.; Jahanbani, S.; Mirjalili, B. F.; Zare, R.; Chin. J. Catal. 2016, 37, 549.

45. Luo, X.; Pan, J.; Yu, Y.; Zhong, A.; Wei, S.; Li, J.; Shi, J.; Li, X.; J. Electroanal. Chem. 2015, 745, 80.

46. Ensafi, A. A.; Abarghoui, M. M.; Rezaei, B.; Electrochim. Acta 2016, 190, 199.

47. Liu, Y.; Chen, S. S.; Wang, A. J.; Feng, J. J.; Wu, X.; Weng, X.; Electrochim. Acta 2016, 195, 68.

48. Zhao, Z.; Sun, Y.; Li, P.; Zhang, W.; Lian, K.; Hu, J.; Chen, Y.; Talanta 2016, 158, 283.

49. Bansal, P.; Bhanjana, G.; Prabhakar, N.; Dhau, J. S.; Chaudhary, G. R.; J. Mol. Liq. 2017, 248, 651.

50. Samanta, S.; Srivastava, R.; J. Electroanal. Chem. 2016, 777, 48.

51. Gao, F.; Wang, Q.; Gao, N.; Yang, Y.; Cai, F.; Yamane, M.; Gao, F.; Tanaka, H.; Biosens. Bioelectron. 2017, 15, 238.

52. Gillani, N. S.; Zizi, S. N.; Ghasemi, S.; Bull. Mater. Sci. 2017, 40, 177

53. Conceição, C. D. C.; Faria, R. C.; Fatibello-Filho, O.; Tanaka, A. A.; Anal. Lett. 2008, 41, 1010.

54. Ahmad, K.; Mohammad, A.; Rajak, R.; Mobin, S. M.; Mater. Res. Express 2016, 3, 074005.

55. Siangproh, W.; Chailapakul, O.; Laocharoensuk, R.; Wang, J.; Talanta 2005, 67, 903.

56. Deroco, P. B.; Melo, I. G.; Silva, L. S. R.; Eguiluz, K. I. B.; Salazar-Banda, G. R.; Fatibello-Filho, O.; Sens. Actuators, B 2018, 256, 535.

57. Malik, P.; Srivastava, M.; Verma, R.; Kumar, M.; Kumar, D.; Singh, J.; Mater. Sci. Eng., C 2016, 58, 432.

58. Wu, M.; Ding, W.; Meng, J. L.; Ni, H. M.; Li, Y.; Ma, Q. H.; Anal. Sci. 2015, 31, 1027.

59. Lee, K. K.; Loh, P. Y.; Sow, C. H.; Chin, W. S.; Biosens. Bioelectron. 2013, 39, 255.

60. Canales, C.; Gidi, L.; Arce, R.; Ramirez, G.; New J. Chem. 2016, 40, 2806.

Submitted: January 15, 2018

Published online: April 18, 2018 